\title{
Spatio-Temporal Analysis of Land Use/Cover Change of Lokoja - A Confluence Town
}

\author{
Nathaniel O. Adeoye ${ }^{1}$ \\ ${ }^{1}$ Department of Geography, Obafemi Awolowo University, Ile-Ife, Osun State, Nigeria \\ Correspondence: Nathaniel O. Adeoye, Department of Geography, Obafemi Awolowo University, Ile-Ife, Osun \\ State, Nigeria. Tel: 234-803-676-9270. E-mail: nadeoye@yahoo.com \& nadeoye@oauife.edu.ng
}

Received: May 18, 2012 Accepted: May 28, 2012 Online Published: September 20, 2012

doi:10.5539/jgg.v4n4p40 URL: http://dx.doi.org/10.5539/jgg.v4n4p40

\begin{abstract}
Land use/land cover information is essential for a number of planning and management activities. The general patterns of land use/cover as they were recorded in remotely sensed data were discussed in this study. Multi-date satellite imageries (Landsat TM 1986, Landsat ETM+ 2001, Landsat ETM+ 2006 of 30m spatial resolution respectively and SPOT 5, 2007 of $10 \mathrm{~m}$ spatial resolution) were obtained and used for the study. These images were enhanced, resampled, georeferenced and classified for the assessment of spatio-temporal pattern of land use/cover change in the study area. The study also utilized topographical map of the study area, derived from sheet number 247 of 1963, scale 1:50,000 to identify features, which were used as ground control point for image geo-referencing. ILWIS 3.2 Academic software was used to process the image data. The result of ground truthing was combined with visual image interpretation as training sites for supervised classification. Six different land uses/covers were identified and used to classify the image data. The results showed that the natural environments (vegetation, wetland resources, water bodies and mountainous terrain) were being threatened, as they reduced continually in the areal extent over time and space while the social environment (built up area) expanded tremendously. The study discovered that urbanization processes majorly responsible for land use/cover change in Lokoja. In conclusion, the study advanced our frontier of knowledge on land use/cover study by providing information on the status of natural and social environment in Lokoja, a confluence town, between 1986 and 2007 using remotely sensed images and Geographic Information Systems (GIS) technology.
\end{abstract}

Keyword: land use/cover, multi-date satellite imageries, image classification, Lokoja, Nigeria

\section{Introduction}

Scientific research community called for substantive study of land use changes during the 1972 Stockholm Conference on the Human Environment, and again 20 years later, at the 1992 United Nations Conference on Environment and Development (UNCED). At the same time, International Geosphere and Biosphere Programme (IGBP) and International Human Dimension Programme (IHDP) co organized a working group to set up research agenda and promote research activity for land use and land cover (LULC) changes. This is because it was realized that land use and land cover (LULC) change is a major issue of global environmental changes (Prakasam, 2010).

Land use and land cover change (LULCC); also known as land change is a general term for the human modification of Earth's terrestrial surface (Ellis, 2011). Scientists and the public alike now understand that contemporary change in many realms of the biosphere is largely the product of human activities (Turner et al. 1994). Some of these activities are due to specific management practices and the rest are due to social, political and economical forces that control land uses (Medley et al., 1995). Although humans have been modifying land to obtain food and other essentials for thousands of years, the current rates, extents and intensities of LULCC are far greater than ever in history, driving unprecedented changes in ecosystems and environmental processes at local, regional and global scales (Turner et al., 1994; Ellis, 2011). As Meyer and Turner (1992) asserted, changes in land use and land cover affect global systems (e.g. atmosphere, climate, forest, and sea level) and have a significant effect in localised places where they occur. Because of their great influence in global warming, loss of biodiversity, and impact in human life, the International Geosphere-Biosphere Program (IGBP) and the International Human Dimension Program (IHDP) initiated a joint international program of study on Land Use /Cover Change (LUCC). They recognized the necessity to improve understanding, modelling, and projecting 
land dynamics from global to regional scale and focusing particularly on the spatial explicitness of processes and outcomes (Geoghegan et al., 2001).

Land use/land cover (LULC) changes in tropical regions are of major concern due to the widespread and rapid changes in the distribution and characteristics of tropical forests (Myers 1993; Houghton, 1994). However, changes in land cover and in the way people use the land have become recognized over the last 15 years as important global environmental changes in their own right (Turner, 2002). In recent times, the knowledge about land use and land cover has become increasingly important as the nation plans to overcome the problems of haphazard, uncontrolled development, deteriorating environmental quality, loss of prime agricultural lands, destruction of important wetlands, and loss of fish and wildlife habitat. Land use data are therefore, needed in the analysis of environmental processes and problems that must be understood if living conditions and standards are to be improved or maintained at current levels (Medley et al., 1995; Anderson et al., 2001).

The study area, Lokoja, is a confluence town, undergone rapid urbanization and tremendous economic growth during the last few years. The growing urbanization in the city has created pressure for the changes in the land use pattern. These changes have rapidly transformed the city from a subsistence agrarian economy into rapidly commercial economy. Infrastructural development such as, road networks, housing estate development among others, has further enhanced land use change in the area. The sharp changes in the land use pattern during the past few years have become matter of concern and this has stimulated the choice of this study area.

As opined by Lambin et al. (2003), remote sensing has an important contribution to make in documenting the actual change in land use/land cover on regional and global scales. And there is a consensus of opinion among scientists that satellite imageries and Geographic Information Systems (GIS) provide a reliable means for adequate and regular monitoring of forest estate and land use change (Burrough, 1990; Goodchild et al., 1993; Ayeni, 2001; Lambin et al., 2003). This study therefore, relied on satellite images and Geographic Information Systems (GIS) to analyze land use and land cover change in Lokoja, a confluence town in Nigeria between 1986 and 2007. Specifically, the study identified and mapped the categories of land use/cover in the study area; analyzed the spatial and temporal pattern and assessed the underlying factors and decision variables for land use change.

\section{The Study Area}

The study area is located between latitude $7^{\circ} 45^{\prime} 27.56^{\prime \prime}$ and $7^{\circ} 51^{\prime} 04.34^{\prime \prime} \mathrm{N}$ and longitude $6^{\circ} 41^{\prime} 55.64^{\prime \prime}$ and $6^{\circ} 45^{\prime} 36.58^{\prime \prime} \mathrm{E}$, within the lower Niger-Benue trough. It has an estimated landmass of $63.82 \mathrm{sq} . \mathrm{km}$. It shares common boundaries with Niger, Kwara, Nassarawa states respectively and the Federal Capital Territory to the north; Benue state to the East; Adavi and Okehi Local Government Areas (LGAs) by the south and Kabba Bunu (LGA) by west (Figures $1 \& 2$ ).

The annual rainfall in the area is between $1016 \mathrm{~mm}$ and $1524 \mathrm{~mm}$ with its mean annual temperature not falling below $27^{\circ} \mathrm{C}$. The rainy season lasts from April to October when the dry season lasts from November to March. The land rises from about 300 metres along the Niger-Benue confluence, to the heights of between 300 and 600 metres above the sea level in the uplands. Lokoja is drained by Niger and Benue rivers and their tributaries. The confluence of the Niger and Benue rivers which could be viewed from the top of Mount Patti is located within the study area. The River Benue is navigable as far as Garua in the rainy season floods, but up to Makurdi in Benue State in the dry season (Ogunjumo, 2000).

The general relief is undulating and characterized by high hills. The Niger-Benue trough is a Y-shaped lowland area which divides the sub-humid zone into three parts. It has been deeply dissected by erosion into tabular hills separated by river valleys. The flood plains of the Niger and Benue river valleys in Lokoja have the hydromorphic soils which contain a mixture of coarse alluvial and colluvial deposits (Areola, 2004). The alluvial soils along the valleys of the rivers are sandy, while the adjoining laterite soils are deeply weathered and grey or reddish in colour, sticky and permeable. The soils are generally characterized by a sandy surface horizon overlying a weakly structured clay accumulation.

The main vegetation type in Lokoja is Guinea savanna or parkland savanna with tall grasses and some trees. These are green in the rainy season with fresh leaves and tall grasses, but the land is open during the dry season, showing charred trees and the remains burnt grasses. The trees which grow in clusters are up to six metres tall, interspersed with grasses which grow up to about three metres. These trees include locust bean, shea butter, oil bean and the isoberlinia trees. The different types of vegetation are not in their natural luxuriant state owing to the careless human use of the forest and the resultant derived deciduous and savanna vegetation. 
The creation of Kogi state on 27th August, 1991 with Lokoja as the capital brought an influx of population to the area due to its status as an administrative headquarters. According to 1991 census, Lokoja had the population of about 77,516 people, which increased to 195,261 in 2006 (Nigeria Official Gazette, 2009). The increase in human population brought rapid development, which modified land use pattern in the area. Agriculture serves as the main occupation of the people. However, the status of the Lokoja as an administrative headquarters brought some institutions into the area, which put many people in the public institutions like the Kogi State Polytechnic, Specialist Hospital and other governmental offices.

The major means of transportation is by road. However, other means of transport is by water especially when goods are to be distributed to locations that are not motorable. The ecological problems in Lokoja include leaching, erosion and general impoverishment of the soil. These problems are compounded by the annual bush burning of the savanna that further exposed the top soil to more erosion. Floods pose problems on the flood plains during the rainy season, while aridity is a problem to several areas at short distances from the rivers during the dry season.

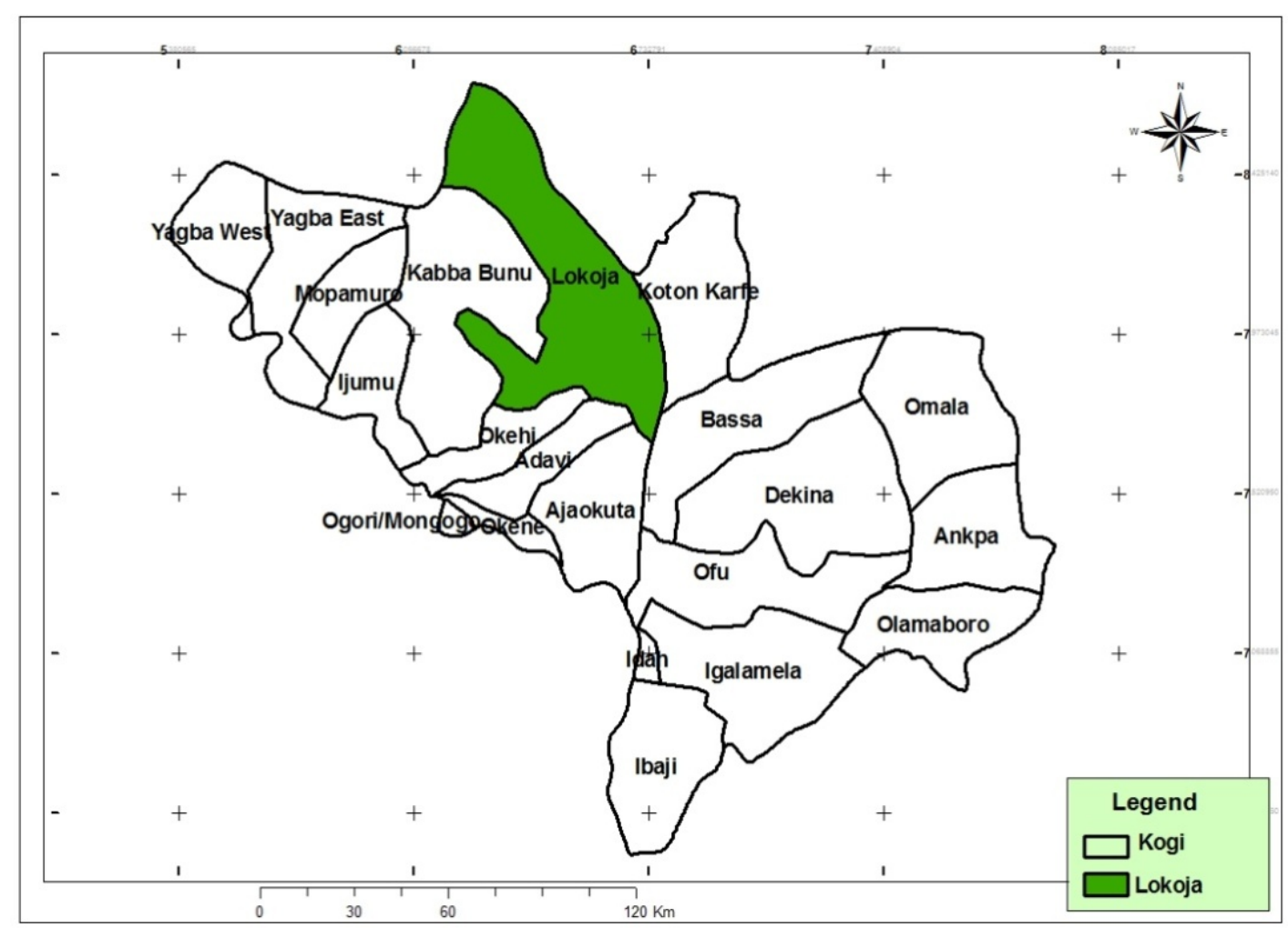

Figure 1. Lokoja and other Local Government Areas in Kogi State 


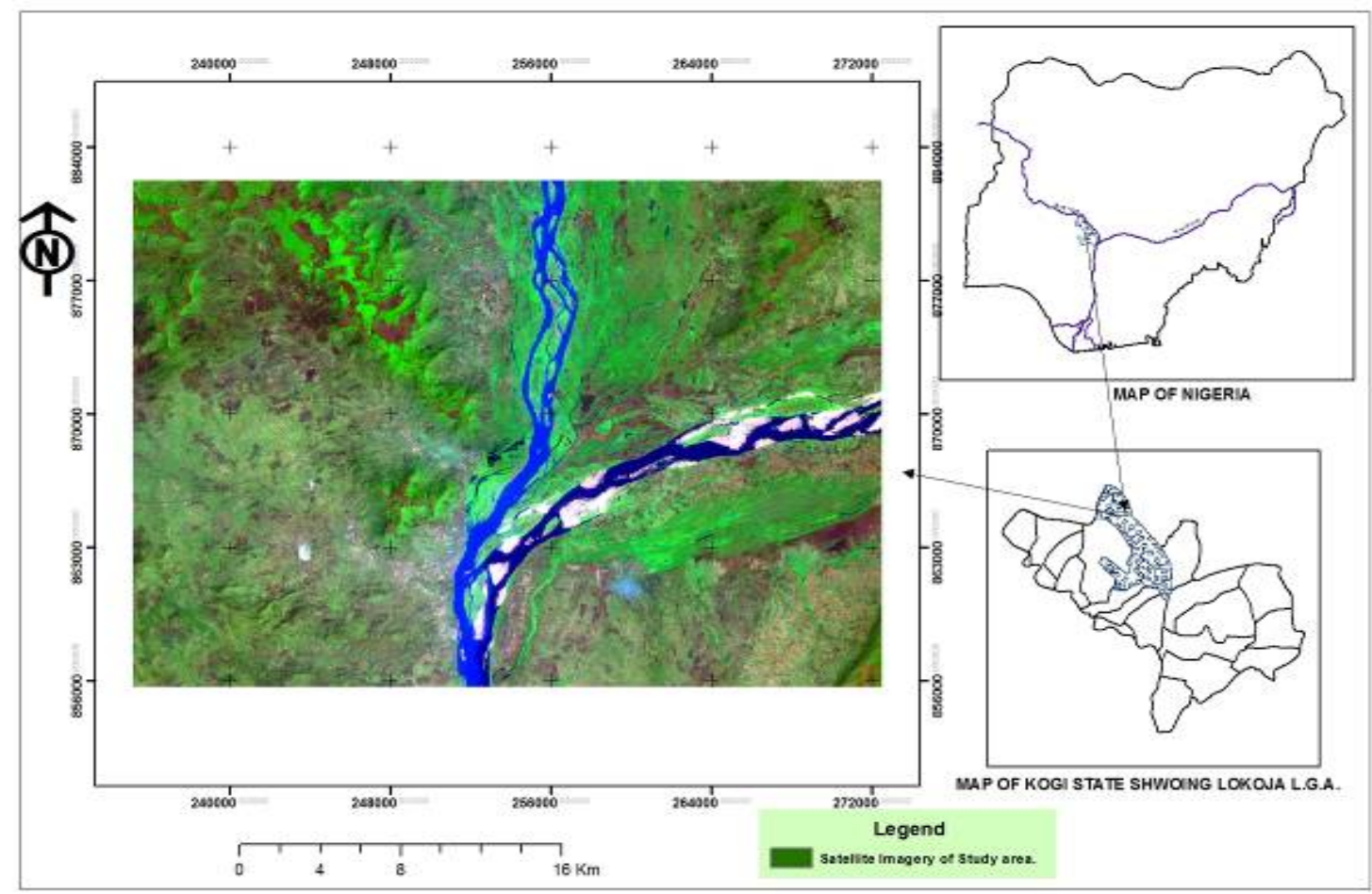

Figure 2. Satellite image of the study area

\section{Materials and Methods}

Multi-date satellite imageries (Landsat TM 1986, Landsat ETM+ 2001, Landsat ETM+ 2006 of 30m spatial resolution respectively and SPOT 5, multispectral 2007 of $10 \mathrm{~m}$ spatial resolution) were obtained and used for the study (Figures 3, 4, 5 \& 6). The images were obtained in the same season (Table 1). While Landsat TM 1986, Landsat ETM+ 2001 and Landsat ETM+ 2006 were obtained in December, January and December respectively, SPOT 5 was obtained in April 2007. It is instructive to note that the rainy season spans the period of seven (7) months (April till October) when the dry season lasts for five (5) months (November till March) in the study area.

All the images were enhanced, resampled, georeferenced and classified for the assessment of spatio-temporal pattern of land use/cover change in the study area. The study also utilized topographical map of the study area, derived from sheet number 247 of 1963, scale 1:50,000, obtained from Federal Survey Office, Lagos. It was used as guide to identify features, which were used as ground control point for image geo-referencing.

The process of digital image analysis begins with the extraction of the sub-scene from the original dataset for all the images used. ILWIS 3.2 Academic software was used to process all the image data. A common window covering the same geographical coordinates of the study area was extracted from the scene of the images obtained. The sub-map operation of ILWIS 3.2 Academic allows the user to specify a rectangular part of a raster map to be used. To extract the study area from the whole scene of the images obtained, the numbers of rows and columns of the area were specified.

To improve the visual interpretation of the image data, all the images were enhanced into natural colour composite. This enabled the image data to relate colours and patterns in the image data to the real world features. In Landsat TM 1986, Landsat ETM+ 2001 and 2006 respectively, channel 7 was assigned to red plane, channel 4 to green plane, and channel 3 to blue plane. This gives Red, Green, Blue, bands (RGB-743), which produced natural colour composite. For SPOT 5, 2007, channel 1 was assigned red plane, channel 2 to green and channel 3 to blue plane. The band combination then consisted of Red, Green and Blue, (RGB-123) natural colour composite. In natural colour composite, vegetation is depicted as green, water in shades of blue and bare soil in shades of brown and gray.

Re-sampling was carried out to equalize the spatial resolution of the datasets that possess varying spatial resolution. The Procedure involved automatically adjusting one or more raster datasets to ensure that the spatial 
resolution of all datasets corresponds for accurate spatial operations. The Landsat images have a spatial resolution of $30 \mathrm{~m}$ while SPOT 5 image was $10 \mathrm{~m}$. Based on these differences, the SPOT image was re-sampled to the nearest neighbour.

GIS data files must have a real-world coordinate system if they are to have valid coverage. To make the image data valid to real world, they were georeferenced to the same coordinate system using the topographical map of the area. The process of georeferencing in this study started with the identification of features on the image data, which can be clearly recognized on the topographical map and whose geographical locations were clearly defined. The intersections of streams and of the highways were used as ground control points (GCPs). The latitude and longitude of the GCPs of visible features obtained in the base map were used to register the coordinates of the image data. Using these ground-control points, the computer produced a number of equations that transformed the location of all the pixels on the distorted image to a properly orientated image. All the images were georeferenced to Universal Transverse Mercator projection of WGS84 coordinate system, zone $31 \mathrm{~N}$ with Clarke 1880 Spheriod.

In this study, the satellite images were classified using supervised classification method. The combine process of visual image interpretation of tones/colours, patterns, shape, size, and texture of the imageries and digital image processing were used to identify homogeneous groups of pixels, which represent various land use classes of interest. This process is commonly referred to as training sites because the spectral characteristics of those known areas were used to train the classification algorithm for eventual land use/cover mapping of the images. To validate the tonal values recorded on the satellite images with the features obtained on the ground and also to know what type of land use/cover was actually present, the study engaged in ground truthing. Before the ground truthing, map of the study area was printed and was used as guide to locate and identify features both on ground and on the image data. The geographical locations of the identified features on the ground were clearly defined. These were used as training samples for supervised classification of the remotely sensed images. Six land uses/land covers were clearly identified during ground truthing, which were used to classify the image data. These are vegetation (savanna, woodland, fallow or shrub), wetlands, bare soils, water body (rivers, streams, ponds and dams), bare rocks and built-up areas.

Table 1. Characteristics of Datasets for the study

\begin{tabular}{|c|c|c|c|c|c|c|}
\hline S/no & Type & Format & Path \& Row & Spectral bands & Scale/Resolution & Date/Source \\
\hline \multirow[t]{2}{*}{1} & Topographic & Analogue & Sheet 247 & & $1: 50000$ & 1963 \\
\hline & & & & & & Federal Survey, Lagos, Nigeria \\
\hline \multirow[t]{2}{*}{2} & Landsat TM & Digital & $189 / 55$ & 7 bands & $30 \mathrm{~m}$ & $21 / 12 / 1986$ \\
\hline & & & & & & $\begin{array}{l}\text { National Centre for Remote Sensing } \\
\text { (NCRS), Jos, Nigeria }\end{array}$ \\
\hline \multirow[t]{2}{*}{3} & Landsat ETM+ & Digital & $189 / 55$ & 7 bands & $30 \mathrm{~m}$ & 09/01/2001 \\
\hline & & & & & & NCRS Jos, Nigeria \\
\hline \multirow[t]{2}{*}{4} & Landsat & Digital & $189 / 55$ & 7 bands & $30 \mathrm{~m}$ & $09 / 12 / 2006$ \\
\hline & ETM+ & & & & & NCRS Jos, Nigeria \\
\hline \multirow[t]{2}{*}{5} & SPOT 5 & Digital & $189 / 55$ & 3 bands & $10 \mathrm{~m}$ & $07 / 04 / 2007$ \\
\hline & & & & & & $\begin{array}{l}\text { Department of Geography, Obafemi } \\
\text { Awolowo University, Ile-Ife, Nigeria }\end{array}$ \\
\hline
\end{tabular}

Source: Author's data analysis 


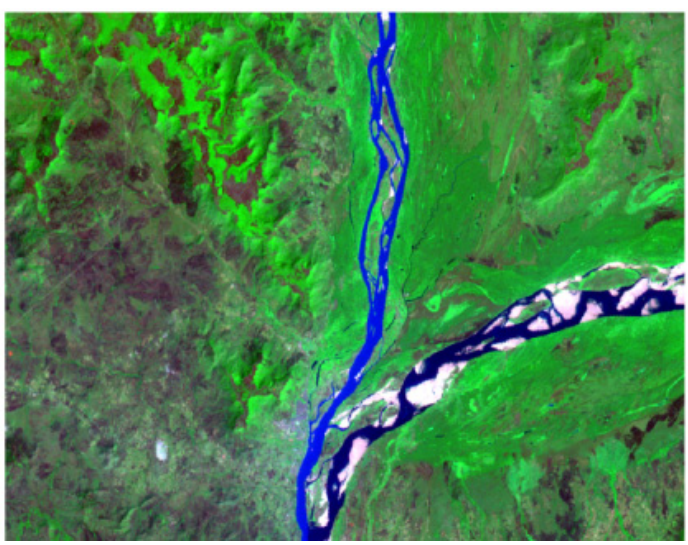

Figure 3. Landsat TM 1986

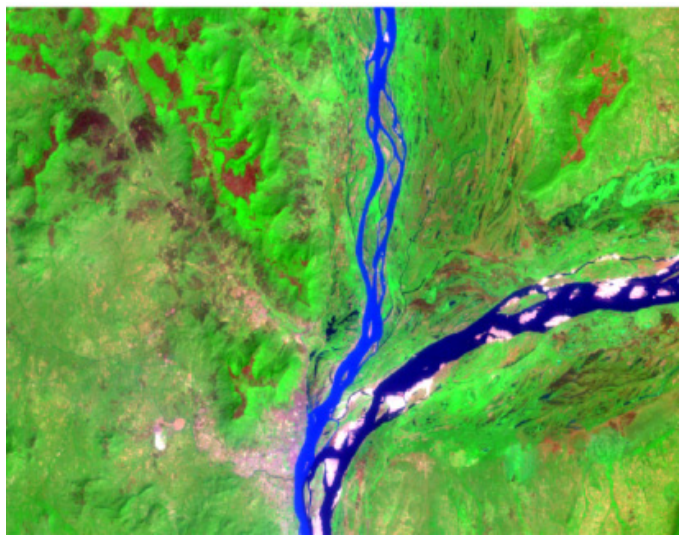

Figure 5. Landsat ETM+ 2006

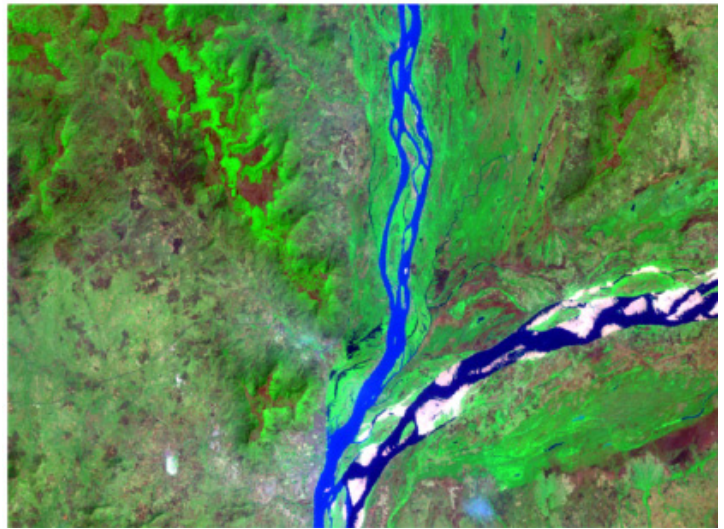

Figure 4. Landsat ETM+ 2001

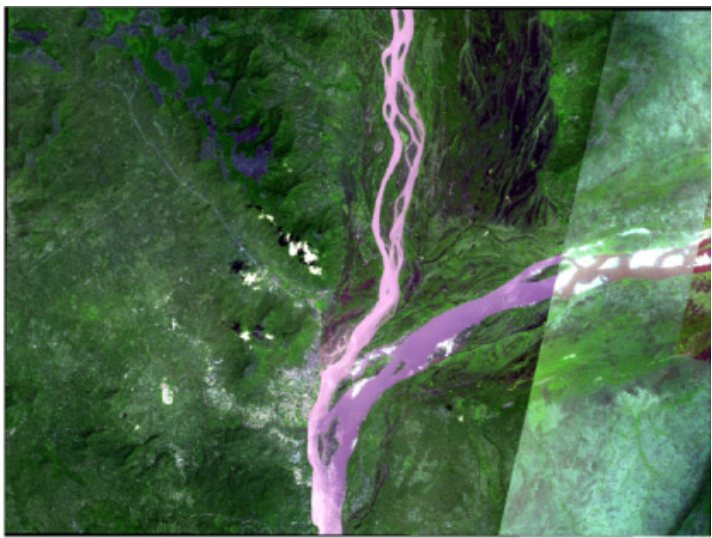

Figure 6. SPOT 52007

\section{Accuracy and Reliability Assessment of the Classified Image}

In order to determine the level of accuracy of the image data, a confusion matrix operation was performed and generated. The accuracy assessment of four temporal data shows that most of the land use types were classified with acceptable level of accuracies and the overall accuracy of the land uses makes the study reliable for planning. The summary of the reliability and accuracy assessment of the classified satellite imageries are depicted in Table 2. The average accuracy of Landsat TM of 1986 was $99.96 \%$ while the average reliability was $99.67 \%$ and overall accuracy was $99.85 \%$. Landsat ETM+ 2001 average accuracy was $76.02 \%$, average reliability $75.80 \%$ and overall accuracy was $74.56 \%$. The average accuracy of Landsat ETM+ data of 2006 showed $87.44 \%$ while the reliability was $82.34 \%$ and its overall accuracy revealed $78.26 \%$. Though the spatial resolution of SPOT 5, 2007 was better than Landsat data, there were some noises in the image data, which to some extent affected the result of the classification. However, the average accuracy and reliability still showed some levels of acceptance. While the average accuracy was $65.09 \%$, the reliability was $90.17 \%$ and the overall accuracy was $49.63 \%$.

Table 2. Accuracy assessment

\begin{tabular}{lllll}
\hline Image Data & Year & Average Accuracy (\%) & Average Reliability (\%) & Overall Accuracy (\%) \\
\hline Landsat TM & 1986 & 99.96 & 99.67 & 99.85 \\
Landsat ETM+ & 2001 & 76.02 & 75.80 & 74.56 \\
Landsat ETM+ & 2006 & 87.44 & 82.45 & 78.26 \\
SPOT 5 & 2007 & 65.09 & 90.17 & 49.63 \\
\hline
\end{tabular}

Source: Author's data analysis 


\section{Results and Discussion}

\subsection{Temporal Pattern of Land Use/Cover between 1986 and 2007}

All the identified land uses/covers experienced changes within the period of 21 years (1986-2007) (Table 3). In 1986, bare rocks occupied 6,598.48 hectares, which represented $6.7 \%$ of the entire land use/cover in the area. In 2001, the land cover manifested an evidence of reduction when the land area covered was 3,808.3965 hectares, representing a reduction of 2,790.08 hectares over the period of 15 years. This may be connected to the quarry activities in some parts of the study area, which consequently reduced the area of bare rocks. In 2006, there seems to be increase in the area of bare rocks $(5,117.82$ hectares) as against what it was in 2001. In reality, the area did not increase but the period of the year at which the image was acquired was responsible for it. It is instructive to note that Landsat ETM+ 2006 was obtained in January, the peak of dry season in the study area when vegetation had dried up, and every land cover including bare rocks is opened up. There was no significant difference in the areal extent of the land cover in 2007 in spite of the improvement in the spatial resolution of the image data. This may be due to a year difference, which was assumed to be too small to record significant changes. The disparity in the area of bare rocks especially between 2001 and 2006 may be due to the variations in the accuracy levels of the classified image data as shown in Table 2. However, the overall change in the areal extent of bare rocks reveals that between 1986 and 2007, the land cover reduced from 6,598.48 to 5,117.81 hectares representing a percentage reduction of $22.4 \%$. It should be noted that since the study area had become the state headquarters, the development of infrastructural facilities had increased, which led to the creation of more quarry sites and in effect reduced the areal extent of the bare rocks.

The area of bare soils decreased steadily with time. In 1986, bare soils covered 949.52 hectares but decreased to 937.01 hectares in 2001, giving a decrease of 12.51 hectares of the land area. In 2006, the land area of bare soils diminished to 723.21 hectares, representing a decrease of 213.8 hectares. There was no much difference in the land area in 2007 as the area decreased by 0.08 hectares, which is not significant probably because of a year difference. It was observed that since the study area had become the capital city, the demand for land for residential and commercial activities increased. Thus, vacant or undeveloped lands situated within the built up areas were acquired. This explains why the area of bare soils decreased steadily. The overall change shows that the area of bare soils decreased by 226.23 hectares, representing a decrease of $23.8 \%$ between 1986 and 2007 (Table 3).

The built up area gained more land areas with time. In 1986, the land use occupied 2,800.72 hectares, which only constituted $2.8 \%$ of the entire land use area. In 2001, the area increased to $38,393.10$ hectares, occupied $38.8 \%$ of the entire area. This shows that between 1986 and 2001, the built up area had increased by 35,592.38 hectares. In 2006, the areal extent of built up area had grown considerably to 47909.04 hectares, which accounted for $48.4 \%$ of the land area. Close examination of Table 3 shows that among the land uses, only built up area increased tremendously. The growth was so much that it gained 45,109.4 hectares from other land covers, amounting to $1610.6 \%$ increase within the period of 21 years (1986 to 2007). This result shows the reality on ground because since 1991 when the study area (Lokoja) became the state headquarters of Kogi state, influx of people from various parts of the country and outside the country for social and economic activities continue to increase. The implication is that, some land uses/covers such as, forest areas were being converted to residential and commercial land uses, which upholds the results of Jaiyeoba (2002) and Adeoye and Ayeni (2010).

Savanna, woodland, fallow and shrub were classified as vegetation in the study. This area decreased with time. In 1986 , the entire area classified as vegetation was $81,009.84$ hectares, which amounted to $81.8 \%$ of the entire land area. In 2001, it decreased to $48,079.27$ hectares, given a loss of 32,930.6 hectares. The trend continued in 2006 when the land area diminished to $39,807.6$ hectares from $48,079.27$, with a loss of $8,271.67$ hectares. In 2007 , similar area of vegetal cover was maintained with the record of 2006. The overall assessment shows that the area of vegetation in the study area decreased by $50.9 \%$ over the period of 21 years. Observation made during the field survey shows that vegetal areas were paving way for residential quarters, industrial areas and expansion of roads, which corroborates with the findings of Olofin (2000); IPCC (2000); FAO (2001); Jaiyeoba (2002) and Adeoye and Ayeni (2010).

The fluctuation in the area occupied by water body as shown in Table 3 could be attributed to recent climatic variability. Even though the images were acquired in the same time period, that is, the period of dry season in the study area, the intensity of rainfall during the raining season as well as the duration of downpour is no longer stable. This in effect could account for the variation in the volume of water and the area occupied by water body. In 1986, the surface area of water body was 3,216.10 hectares but increased to 3,950.95 hectares in 2001. In 2006 , the area decreased to $3,566.31$ hectares, giving a decline of 384.65 hectares. It should be noted that some 
streams and rivers dried up during the dry season including part of rivers Niger and Benue. The decline thus, means that the volume of water in the river basin reduced whereas the river banks remained the same. The record of 2007 was not different from that of 2006 in spite of the low accuracy level in Table 2.

Most farming activities were done on wetland areas. The wetlands in the study area revealed evidence of reduction in size and area. In 1986, it occupied 4,487.28 hectares but decreased to 1,937.49 hectares by 2007, representing loss of 2,549.79 hectares, which is $56.8 \%$ loss. The decrease in the areal extent of the ecosystem could be attributed to the influx of people into the area, which put more pressure on the limited resources including the wetlands. For instance, places that were used for urban agriculture were converted to filling stations, shopping malls and residential area. During the field survey, it was observed that wetland areas that were zone of flora and fauna ecosystems were subsequently converted to Fadama cropping, residential quarters and commercial centres. The implication is that if nothing is done to protect this ecosystem, there may be an increase in urban disasters such as flooding, which wetlands can mitigate.

Table 3. Temporal pattern of Land use/cover between 1986 and 2007

\begin{tabular}{|c|c|c|c|c|c|c|c|c|c|c|}
\hline \multirow{2}{*}{$\begin{array}{l}\text { Land use/cover } \\
\text { type }\end{array}$} & \multicolumn{2}{|c|}{1986} & \multicolumn{2}{|c|}{2001} & \multicolumn{2}{|c|}{2006} & \multicolumn{2}{|c|}{2007} & \multicolumn{2}{|c|}{ 1986-2007 } \\
\hline & $\begin{array}{l}\text { Area } \\
\text { (ha.) }\end{array}$ & $\%$ & $\begin{array}{l}\text { Area } \\
\text { (ha.) }\end{array}$ & $\%$ & $\begin{array}{l}\text { Area } \\
\text { (ha.) }\end{array}$ & $\%$ & $\begin{array}{l}\text { Area } \\
\text { (ha.) }\end{array}$ & $\%$ & $\begin{array}{l}\text { Overall change } \\
\text { (ha.) }\end{array}$ & $\%$ change \\
\hline Bare rocks & 6598.48 & 6.7 & 3808.40 & 3.8 & 5117.82 & 5.2 & 5117.81 & 5.2 & $\begin{array}{l}-1480.67 \\
\text { (Decrease) }\end{array}$ & $-22.4 \%$ \\
\hline Bare soils & 949.52 & 1.0 & 937.01 & 1.0 & 723.21 & 0.7 & 723.29 & 0.7 & $\begin{array}{l}-226.23 \\
\text { (Decrease) }\end{array}$ & $-23.8 \%$ \\
\hline Built up Area & 2800.72 & 2.8 & 38393.12 & 38.8 & 47909.04 & 48.4 & 47910.12 & 48.4 & $\begin{array}{l}+45109.4 \\
\text { (Increase) }\end{array}$ & $+1610.6 \%$ \\
\hline Vegetation & 81009.83 & 81.8 & 48079.27 & 48.5 & 39807.60 & 40.2 & 39806.81 & 40.2 & $\begin{array}{l}-41203.02 \\
\text { (Decrease) }\end{array}$ & $-50.9 \%$ \\
\hline Water Body & 3216.10 & 3.3 & 3950.95 & 4.0 & 3566.31 & 3.6 & 3566.30 & 3.6 & $\begin{array}{l}+350.2 \\
\text { (Increase) }\end{array}$ & $+10.9 \%$ \\
\hline Wetlands & 4487.28 & 4.5 & 3894.09 & 4.0 & 1938.84 & 2.0 & 1937.49 & 2.0 & $\begin{array}{l}-2549.79 \\
\text { (Decrease) }\end{array}$ & $-56.8 \%$ \\
\hline Total & 99061.93 & 100 & 99062.84 & 100 & 99062.82 & 100 & 99061.82 & 100 & & \\
\hline
\end{tabular}

Source: Author's data analysis

$>\quad$ Overall change $=($ Final area - Initial Area $)$

$>$ Percentage change $=[($ Final area - Initial Area $) /$ Initial Area $] * 100$

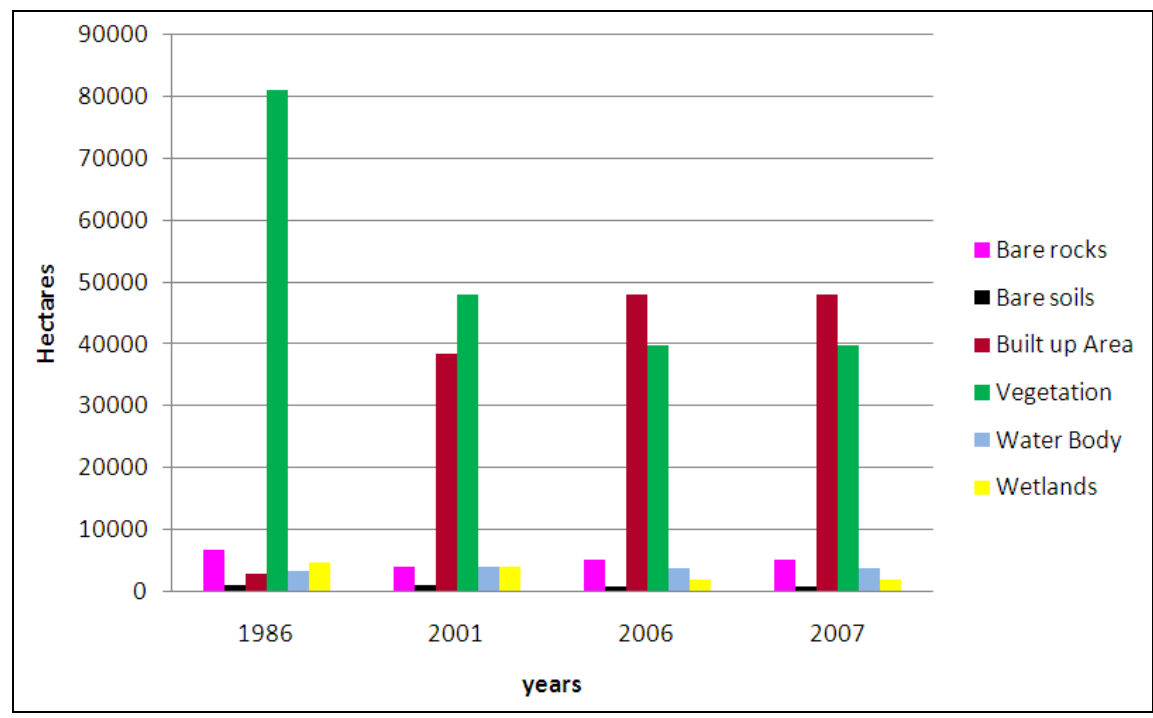

Figure 7. Temporal Pattern of Land use/cover between 1986 and 2007 


\subsection{Spatial Pattern of Land Use/Cover between 1986 and 2007}

Exposed rocks, otherwise termed as bare rocks were mostly found in the western part of river Niger (Figure 8). The mountainous terrain decreased tremendously as the city expanded, leaving the land cover to the north western part of river Niger and few patches to the north of river Benue (Figures 9, $10 \& 11$ ). The reason was due to the influx of people to the study area when it became the state headquarters in 1991. At this time, more quarry sites were opened to cope with high demand of stones for road construction and housing projects. This consequently affected the original area of the land cover.

The undeveloped lands, uncultivated and exposed lands especially along rivers Niger and Benue were classified as the bare soils in the study. In 1986, it was not a common feature though found in few locations void of vegetation (Figure 8). Between 2001 and 2007, the land cover became one of the prominent features because of the status of the study area as the political headquarters. Most lands were exposed and left uncultivated. However, there were variations in their spatial expansion with time (Figures 9, 10 \& 11).

The built up areas expanded across rivers Niger and Benue with time. Many rural settlements around Lokoja were brought to the limelight because of the status of the area. Besides, many newly residential quarters sprang up and spread across the Niger (Figures 8, 9, $10 \& 11$ ). In 1986, the built up areas were majorly found at lower Niger but expanded to both sides of river Niger and Benue with several settlements and newly developed residential quarters, which varied in sizes (Figures 9, $10 \& 11$ ). This was as a result of increase in human population, which increased man's needs for shelter and places of commercial activities.

The vegetation of the study area is evergreen especially during the wet season when the savanna vegetation and the riparian vegetation found along the river courses are found in their brighter state. Observation made during the field survey revealed that savanna were set on fire by the unidentified people, which often turned the field brown during the dry season. The vegetation was almost gone in 2006 as the expansion of the residential quarters seriously encroached into the area covered by vegetation.

The areas covered with shallow water or water logged, swampy/marshy and muddy was found all over the study in 1986 especially around river Niger and Benue (Figure 8). But the spatial coverage became thinner and thinner with time owned to the expansion of settlement and anthropogenic activities. The study area is a confluence town that is, the town at which river Niger and river Benue meet thus, water body is a prominent features. However, the variation in the spatial pattern is dictated by the seasonal variations, climatic variation and the period at which the image data were obtained (Figures 8, 9, $10 \& 11$ ).

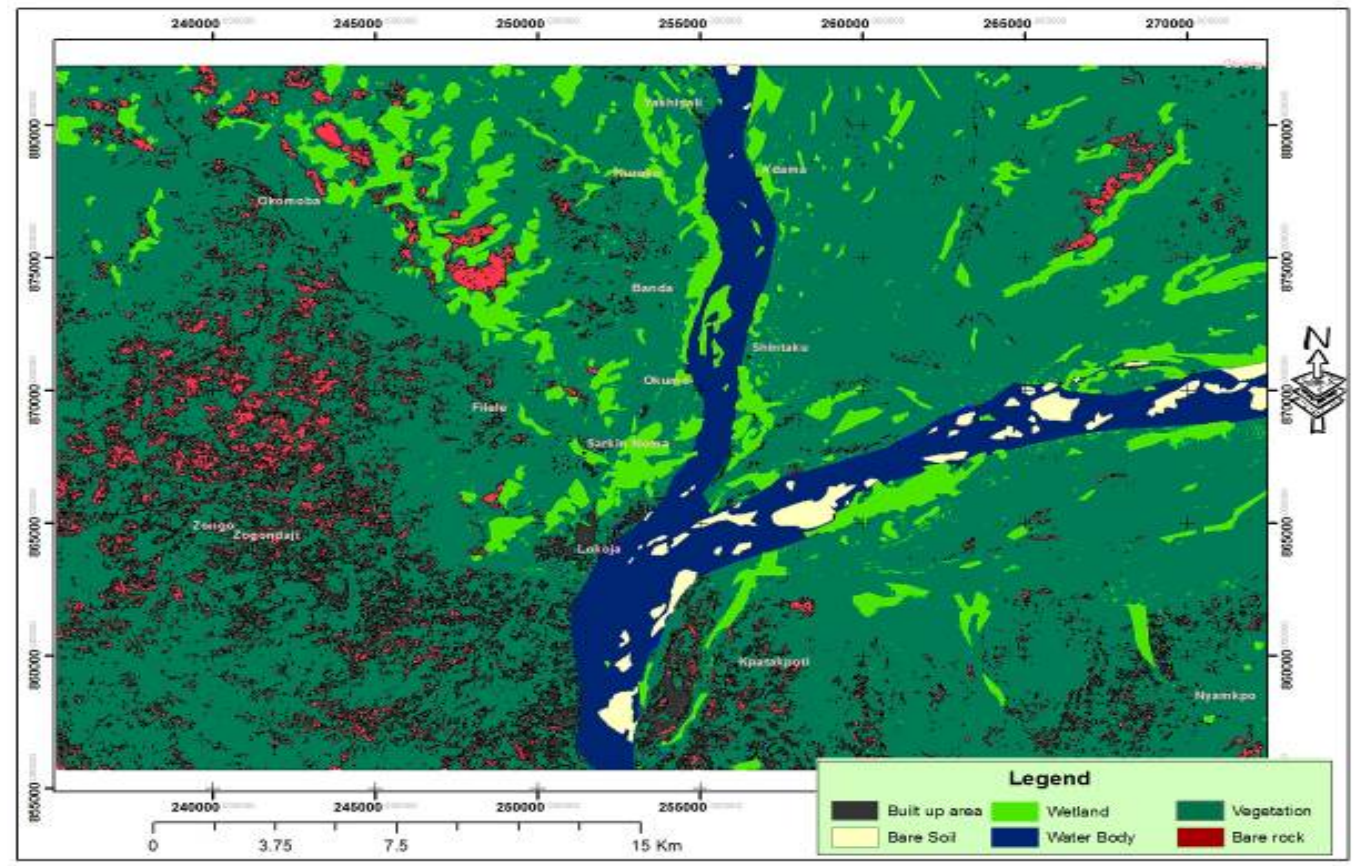

Figure 8. Land use/cover in 1986 


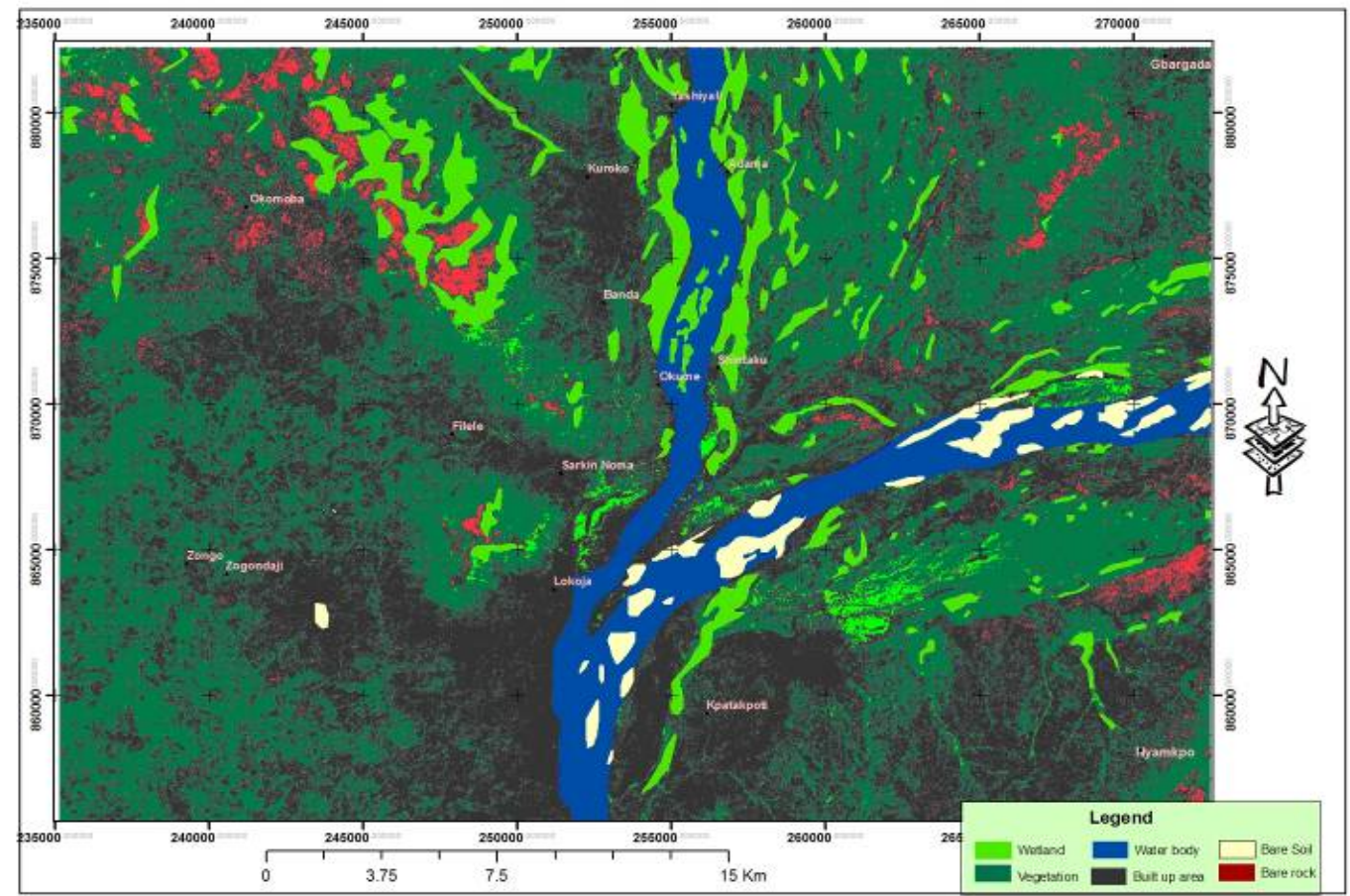

Figure 9. Land use/cover in 2001

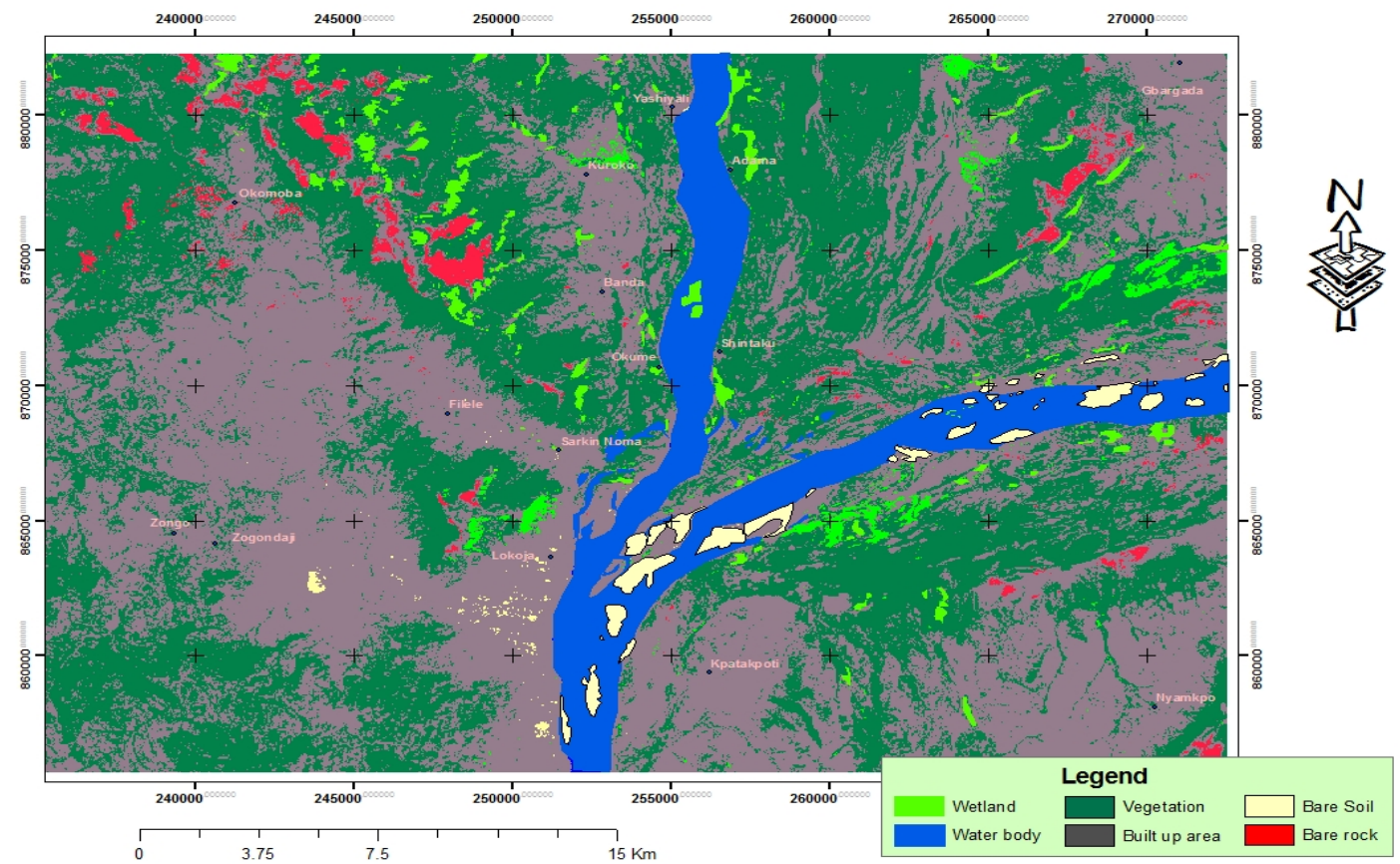

Figure 10. Land use/cover in 2006 


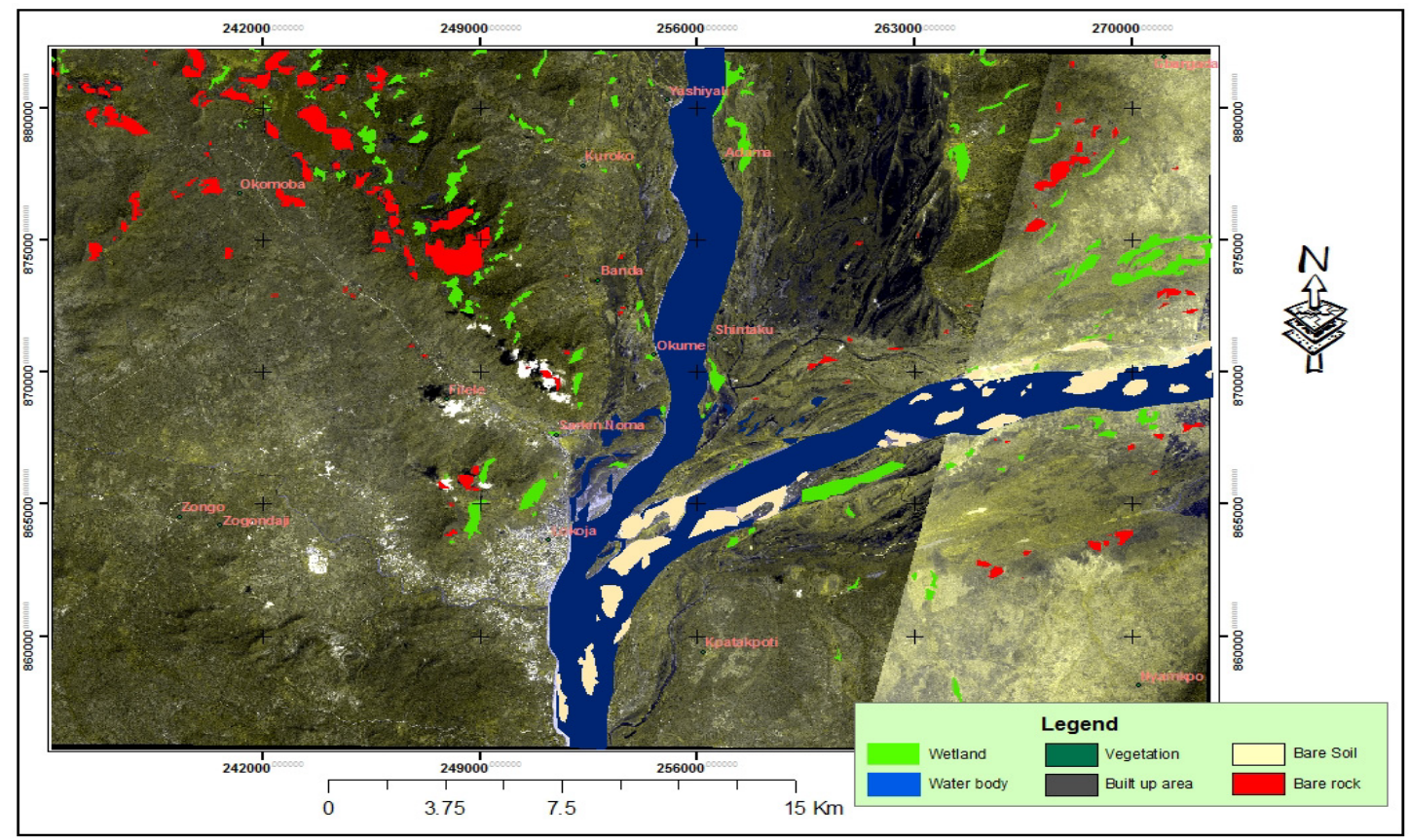

Figure 11. Land use/cover in 2007

\section{Conclusion}

According to Geist et al. (2005), one of the key activities of land use/cover change project is to generate synthesis of knowledge on land use/cover change processes, and in particular to advance understanding of the causes and trajectories of land change. This study has contributed to the frontier of knowledge of land use/cover study by providing information on the status of natural and social environment in Lokoja, the confluence town in Nigeria between 1986 and 2007 using remotely sensed images and GIS technology. It is evident in the study that the natural environment (vegetation, rocks and wetland resources) were being threatened while the social environment (settlement or built up area) was expanding. This is not unconnected with the recent influx of people into the study area, when it became the political headquarters. The increase in human population attracted infrastructural development and expansion of housing estate, which consequently impacted negative influence on the natural environment. From the study, it is obvious that urbanization processes majorly contributed to land use/cover change in Lokoja. It is therefore, necessary that the natural environments be protected by our urban planners and policy makers owning to tremendous social and economic benefits they offer to man.

\section{Acknowledgements}

The author valued the contributions of Yusuf M. J. and Babatunde E. O., the Masters students of Remote Sensing and GIS 2006/2007 academic session of the Department of Geography, Obafemi Awolowo University, Ile-Ife, Nigeria who processed the image data.

\section{References}

Adeoye, N. O., \& Bola, A. (2010). Assessment of Deforestation, Biodiversity Loss and the Associated Factors in Ijesa-Ekiti Region of Southwestern Nigeria. GeoJournal, 76, 229-243. http://dx.doi.org/10.1007/s10708-009-9336-z

Anderson, J. R., Hardy, E. E., Roach, J. T., \& Witmer, R. E. (2001). A Land Use and Land Cover Classification System for Use with Remote Sensor Data. U.S. Geological Survey Circular 671, United States Government Printing Office, Washington, DC.

Areola, O. (2004). Kogi State Physical Setting, People, Population and Rural Urban Settlement. Retrieved from www.onlinenigeria.com/links/kogiadv.asp?blurb=306

Bola, A. (2001). Application of GIS. A paper presented at the $44^{\text {th }}$ Annual Conference of Nigerian Geographical Association, University of Ibadan, July 2001 
Burrough, P. A. (1990). Principles of Geographical Information Systems for Land Resources Assessment. Monographs on Soil and Resources Survey. Oxford: Clarendon Press, No. 12.

Ellis, E. (2011). Land-use and land-cover change, in: Cutler J. Cleveland (ed.), The Encyclopedia of Earth, Environmental Information Coalition, National Council for Science and the Environment, April 18, 2010. Retrieved November 26, 2011, from http://www.eoearth.org/article/Land-use_and_land-cover_change

Food and Agricultural Organization (FAO). (2001). Forest Resources Assessment 2000, Global Forest Resources Assessment 2000 main report, FAO Forestry 140 (2001a), Rome. Retrieved from www.fao.org/forestry/fo/fra/main/index.jsp

Geoghegan, J., Villar, S. C., Klepeis, P., Mendoza, P. M., Yelena, O., Chowdhury, R. R., ... Vance, C. (2001). Modeling Tropical Deforestation in the Southern Yucatan Peninsular Region: Comparing Survey and Satellite Data. Agriculture, Ecosystems and Environment, 85, 25-46. http://dx.doi.org/10.1016/S0167-8809(01)00201-8

Goodchild, F. M., Bradley, O. P., \& Steyaert, T. L. (1993). Environmental Modeling with GIS. New York: Oxford University Press Inc.

Houghton, R. A. (1994). The Worldwide Extent of Land-use change. BioScience, 44, 305-313. http://dx.doi.org/10.2307/1312380

IPCC, (2000). Land Use, Land-use Change, and Forestry, Intergovernmental Panel on Climate Change. Cambridge: Cambridge University Press.

Jaiyeoba, I. A. (2002). Environment, Africa Atlases, Atlas of Nigeria, Paris, Les Edition, JA, pp. 122-123.

Lambin, E. F., Geist, H., \& Lepers, E. (2003). Dynamics of Land use and cover change in Tropical Regions. Annual Rev. Environ. Resour., 28, 205-241. http://dx.doi.org/10.1146/annurev.energy.28.050302.105459

Medley, K. B., Okey, G., Barrett, M., \& Lucas, W. R. (1995). Landscape Change with Agricultural Intensification in a Rural Watershed, Southwestern Ohio, USA. Landscape Ecology, 10(3), 161-176. http://dx.doi.org/10.1007/BF00133029

Meyers, W. B., \& Turner II, B. L. (1992). Human Population Growth and Global Land use/land cover change. $\begin{array}{llllll}\text { Annual Review of Ecology and } & \text { Systematics, } & \text { 23, }\end{array}$ http://dx.doi.org/10.1146/annurev.es.23.110192.000351

Myers, N. (1993). Tropical forests: the main deforestation fronts. Environ. Conserv., 20, 9-16. http://dx.doi.org/10.1017/S0376892900037176

Ogunjumo, A. (2000). 'Kogi State', in: Mamman, A. B., Oyebanji, J. O., \& Petters, S. W. (eds.), Nigeria, A People United, A Future Assured, Abuja, Federal Ministry of Information, Gabumo Publishing Co. Ltd, 2, pp. 323-324.

Olofin, E. A. (2000). Geography and Environmental Monitoring for Effective Resource Management. The Nigerian Geographical Journal, New series, 3\&4, 5-8.

Prakasam, C. (2010). Land use and Land cover Change Detection through Remote Sensing Approach: A case study of Kodaikanal taluk, Tamil nadu. International Journal of Geomatics and Geosciences, 1(2).

Turner II, B. L. Meyer, W. B., \& Skole, D. L. (1994). Global Land-Use/Land Change: Towards an Integrated Study. Integrating Earth System Science, 23(1), 91-95.

Turner II, B. L. (2002). Toward Integrated Land-change Science: Advances in 1.5 Decades of Sustained International Research on Land-use and Land cover Change, Steffen, W., Jäger, J., Carson, D. J., \& Bradhsaw, C. (eds.), Challenges of a Changing Earth, Berlin, Springer, pp. 21-26. 